\title{
Южная Карелия в конце эпохи Средневековья
}

\begin{abstract}
Кузьмин Денис Викторович, КарНЦ РАН (Петрозаводск); kusmiccu@hotmail.com
В статье рассматривается ряд вопросов, связанных с историей заселения южной Карелии в период до освоения ее территории современными карелами. Археологические данные свидетельствуют, что регион исследования был заселен около 9 тысяч лет назад, и представленные здесь археологические культуры поэтапно сменяли друг друга на протяжении всего этого времени, вплоть до эпохи Средневековья. В то же время, исследователи не могут точно определить, носителями каких языков были представители палеоевропейского населения Фенноскандии, на смену которому приходят предки современных саамов. Таким образом, наиболее ранний из достоверно определяемых пластов в языках и топонимии народов современной Карелии является (пра)саамским по происхождению. Следы этого пласта лучше всего сохранились в топонимии, а также в заимствованной в карельский, вепсский и русский языки лексике. Прибалтийско-финское население южной Карелии также является достаточно древним, при этом его основу составили представители средневековых вепсов, которые с X века н. э. начали поэтапное освоение южных частей Карелии. С ХІІІ века территорию Карелии начинают активно осваивать древние карелы, чья прародина находилась в северо-западном Приладожье. Со временем приладожские карелы ассимилировали и автохтонное саамское население Карелии, и большую часть переселившихся сюда вепсов.
\end{abstract}

\section{SOUTH KARELIA AT THE END OF THE MIDDLE AGES}

Denis V. Kuzmin, Karelian Research Centre, RAS (Petrozavodsk); kusmiccu@,hotmail.com

The article discusses a number of issues related to the history of the settlement of south Karelia in the period before the colonization of its territory by modern Karelians. Archaeological evidence suggests that the region of study became inhabited about 9 thousand years ago, and the archaeological cultures emerged here gradually replaced each other throughout this time, up to the era of the Middle Ages. At the same time, researchers cannot determine exactly which languages were spoken by the local populations of the paleo-European archaeological cultures of Fennoscandia, which had been replaced by the ancestors of modern Sami. Thus, the earliest of reliably identifiable strata in the languages and toponymy of the peoples of modern Karelia is of (pre-)Sami origin. Traces of this layer are best preserved in toponymy, as well as in borrowed vocabulary in the Karelian, Vepsian and Russian languages. The Baltic-Finnish population of southern Karelia is also quite ancient, and it originated from the medieval Vepsians, who from the $10^{\text {th }}$ century A. D. began the gradual settlement of the southern parts of Karelia. From the $13^{\text {th }}$ century, the territory of Karelia began to be actively colonized by ancient Karelians, whose historic homeland was in the northwestern Ladoga area. Over time, the Ladoga Karelians assimilated both the autochthonous Sami population of Karelia, and most of the Veps who moved here from the Svir river area.

Исследование выполнено при финансовой поддержке РФФИ в рамках научного проекта № 19-012-00068 А «Ойконимическая система южной Карелии: на стыке традиций и инноваций». 
Эпоха Средневековья стала важным периодом с точки зрения формирования языков и культуры прибалтийско-финских народов Карелии, поскольку именно в этот период происходило становление карельского и вепсского этносов на территории современной Ленинградской области. Позднее, в эпоху Высокого Средневековья (XI-XIV в.), древние карелы и вепсы начинают освоение современной южной Карелии, переселяясь со своей прародины на север и северо-восток.

\section{Археологическое наследие территории}

Территория Карелии является областью давних этнических и языковых контактов. Согласно археологическим данным, в Карелии выявляется, по крайней мере, девять культурно-хронологических пластов и типов древностей, которые, начиная с эпохи мезолита, сменяют друг друга на протяжении девяти тысяч лет, вплоть до эпохи позднего Средневековья [Косменко 1996а: 18].

Новопоселенцы мезолитической эпохи были рыболовами и охотниками на северного оленя и лося. Костные останки этих промысловых животных часто встречаются на берегах озер в местах стоянок человека того времени. В данный период можно говорить о двух отдельных археологических группах находок, которые представляют две разные культуры. Одна из них бытовала в окрестностях Онежского озера, другая - в северной и северо-западной части современной Карелии.

Археологи не могут дать ответа, кем были представители этих доисторических культур и на каком языке они говорили. Несмотря на это, культуру эпохи бронзы в Карелии, для которой была свойственна текстильная керамика, археологи считают наиболее ранней местной финно-угорской культурой [Косменко 2008: 23].

Во второй половине эпохи железного века, а также в раннем Средневековье в Карелии развивается культура лесных саамов [Косменко, Кочкуркина 1996: 379]. Так, например, в западной и северной частях Карелии, а также в восточной и средней частях современной Финляндии превалировала культура лууконсаари (сер. I тыс. до н. э. - II пол. I тыс. н. э.), которая принадлежала древнесаамскому населению [Косменко 2008: 23]. К этой культуре относились в том числе поселения, обнаруженные в южных частях Олонецкой Карелии, в частности в Сямозерье.

Раннесредневековые памятники южных частей Карелии археологи относят к двум территориальнокультурным группам. Для первой характерна грубая лепная керамика, основным ареалом распространения которой являются южные части бассейна Онежского озера, включая территорию устья реки Выг и Сямозерье. Вторая - в западной и северной части Карелии - характеризуется стоянками-поселениями без керамики [Косменко 1996б: 272]. Археологические памятники без керамики были распространены на рубеже первого и второго тысячелетий на территории всей восточной Фенноскандии, и их связывают с проживанием здесь древнесаамского населения [Косменко, Кочкуркина 1996: 379]. В Сямозерье, например, поселения без керамики датируются периодом X-XII веков, при этом единичные находки относятся к XIV веку [Косменко 2008: 23]. На севере, а также во внутренних частях Финляндии этот период истории (IV-XI вв. н. э.) именуют «саамским железным веком», для которого также характерно небольшое количество археологических находок.

С древними вепсами, согласно археологическим данным, соотносятся поселения позднего железного века (начало Раннего Средневековья) в южных частях Олонецкой Карелии и на северном побережье Онежского озера, для которых характерна грубая лепная керамика. Этот тип близок керамике, обнаруженной в курганах юго-восточного Приладожья и датируемой тем же временем [Косменко 1996а: 21; 2008: 24].

\section{Саамы}

Наиболее ранний из достоверно определяемых пластов топонимии в Карелии является (пра)саамским по происхождению. Считается, что население, говорившее на прасаамском языке, проживало на юге Карелии еще в первых веках второго тысячелетия нашей эры. Таким образом, к началу $\mathrm{XIX}$ в. саамы ${ }^{1}$ являлись автохтонным населением исследуемого региона уже на протяжении нескольких

\footnotetext{
${ }^{1}$ Саамы - коренной народ Северной Фенноскандии, языки которого относятся к финно-угорской ветви уральской языковой семьи. Отделение прасаамского от прибалтийско-финского праязыка произошло на фоне контактов носителей последнего с древними балтами и древними германцами. Кроме этого, важной составляющей данного процесса стали контакты и последующая ассимиляция предками современных саамов древнейшего палеоевропейского населения северной Европы, которое говорило на языках, не относящихся к современным языковым семьям и не оставивших прямых языковых потомков. Доказательством этого является присутствие во всех саамских язы-
} 
сотен лет. При этом последние их представители на самом севере современной республики окончательно перешли на карельский язык в первой трети XIX в. [Рӧ1lä 2001: 97]. Свидетельством процесса ассимиляции является, например, саамская по происхождению лексика современных говоров карельского и русского языков, некоторые черты карельской культуры, а также топонимия саамского происхождения на всей территории Карелии.

Археологи КарНЦ РАН, определяя период, совпадающий с хронологическими рамками железного века (середина I тыс. до н. э. - І тыс. н. э.), как саамский [Косменко, Кочкуркина 1996: 379], не видят на территории современной Карелии археологических проявлений древнесаамской культурноисторической общности до начала первых веков второго тысячелетия нашей эры и связывают ее, таким образом, только со временем Высокого Средневековья (XI-XIV вв.). Стоит все же отметить, что, согласно исследованиям скандинавских ученых, распространение древнесаамского населения в Швецию через самую узкую часть Ботнического залива с востока должно было произойти не позднее IX-X вв. первого тысячелетия [Bergsland 1995]. Именно на такую хронологию указывает анализ особенностей саамской субстратной топонимии центральных частей Швеции. В связи с этим можно напомнить, что формирование прасаамской языковой общности происходило в первые века первого тысячелетия нашей эры в условном треугольнике между Белым, Ладожским и Онежским озерами [Saarikivi 2011: 113]. С распадом саамского праязыка образовалось два диалекта — северный и южный [Korhonen 1981: 49-50]. К последнему относилось население, осваивавшее в свое время территории южных частей современной Карелии и Финляндии. Именно носители южного диалекта должны были достигнуть центральных частей Швеции не позднее рубежа X-XI в., о чем свидетельствуют данные фонетической адаптации скандинавской топонимии саамами. Указанный факт позволяет осторожно предположить, что освоение древнесаамским населением территории южной Карелии могло произойти достаточно рано. Только после этого далекие предки нынешних шведских саамов должны были продвинуться на запад, на восточное побережье Ботнического залива, а затем и пересечь его. В связи с вышеуказанным возникает вопрос, не с распространением ли этого населения можно увязывать находки в южных частях Карелии, относимые к середине первого тысячелетия нашей эры?

В позднесредневековых, а также наиболее ранних исторических документах, касающихся Карелии, нет сведений о саамском ${ }^{2}$ населении на Олонецком перешейке или в южной Карелии. Данный факт все же не противоречит тому, что саамы проживали в то время в пределах этой территории. Опосредованно на это может указывать, в частности, написанное в XV в. жизнеописание Лазаря Муромского. Лазарь основал свою обитель на восточном берегу Онежского озера в середине XIV в. В жизнеописании сообщается о «жалобах» святого по поводу его притеснения местным аборигенным населением, среди которого упоминаются лопь 'саамы' и чудь '? вепсы') [Пашков 2003: 7].

Более ранних сведений о саамском населении наука пока не имеет, однако опосредованно на это опять-таки могут указывать некоторые другие источники. Так, в начале XVII в. от жителей Поросозера

ках, а также в топонимии, в том числе бывших саамских территорий, мощного дофинноугорского субстрата, представляющего собой следы языков древнейшего населения севера Европы. В топонимии Карелии также просматривается палеоевропейское наследие (см. ниже), хотя в ее южной части четких следов этого пласта нет, зато присутствует топонимия финно-угорского/западноуральского происхождения [Saarikivi 2006]. Проживающие в республике карелы называли саамов lappi или lappalaine, русские же, в свою очередь, именовали их лопарями, лоплянами или лопью.

${ }^{2}$ Из Устава князя Ярослава (Устав Ярослава о мостех) известно, что в XIII веке Новгородское княжество административно делилось на 19 сотен (ста), одна из которых имела название Лопская ста (также Лопская рель) и относилась в то время к Обонежской волости [НПЛ 1950: 507]. Позже в договоре Новгорода и польского короля Казимира 1471 г. упоминается административная единица Лопца или Лопская волость, которая граничила на западе с Ижорской землей, а на востоке доходила до реки Волхов в окрестностях Ладоги. На севере Лопская волость ограничивалась Ладожским озером и истоками реки Нева [ПРП 1953: 249, 264]. Считается, что в 1500 г. Лопская волость представляла собой Лопский Егорьевский погост, который находился по бо́льшей части на территории современного Кировского района Ленинградской области.

Можно упомянуть также, что в 1500 г. в Лопском Егорьевском погосте существовала деревня Поташово в Сoсари, в которой проживал Поташ Лопин, а в Ладожском Городенском погосте - деревня Легмасарь, где упоминается Гурейко Лопин [ПКВП: 12, 259]. В то же время остается не вполне понятным, на что указывало наименование Лопин в этих документах. Можно предположить, что его фиксация указывала на потомков ассимилированных не так давно саамов, которые проживали некогда в окрестностях южного побережья Ладожского озера. Нельзя, таким образом, исключать, что именно благодаря этому населению административная единица Лопская ста (позднее Лопский Егорьевский погост) получила свое название. 
Селецкого погоста записано «предание под присягой», согласно которому саамское население проживало здесь еще в середине XV в. [История Карелии: 90]. Согласно письменным источникам XVI в., места проживания саамов фиксируются на севере бывшей Олонецкой губернии, а также в Беломорской Карелии.

Можно отметить, что в Обонежской пятине в 1563 г. на Заонежском полуострове существовала деревня Лопинская, которая располагалась на Большом Клименецком острове Кижского погоста. В этом же году деревня с таким же названием фиксируется на берегу Корбо-озера (так в источнике) в Пудожском погосте. В 1496 г. в Шунгском погосте этой же пятины упоминается местность с названием Лоnская матка [ПКОП: 4, 133, 178]. Кроме этого, вблизи побережья Онежского озера между Повенцом и Чёлмужами существовала еще в XX в. деревня Лопская. Согласно одному из народных преданий, первыми жителями этой деревни были именно лопари [Криничная, Пулькин 1971]. В другом устном предании, записанном в западной части Архангельской области, сообщается, что первонасельниками окрестностей Кенозера также были лопари (полевые материалы Паули Рахконен, устное сообщение). В то же время вопрос о языковой и этнической принадлежности лопарей этого территории остается пока открытым и дискуссионным.

Приблизительно с XIII в. заселенные ранее саамами территории южных частей Карелии начало осваивать древнекарельское население, и впоследствии они вошли в состав Корельской земли Водской пятины. В позднем Средневековье здесь стали появляться постоянные карельские поселения. Со временем эту территорию, начинавшуюся узким клином в северной части Сямозерья и простиравшуюся на север до современной южной границы с Мурманской областью, стали называть Лопскими погостами (кар. Lappela, pус. Лешья Лопь) [Жуков 2004: 313]. Данное название, без сомнения, свидетельствует, что автохтонным населением этого региона были именно саамы-лопари. В качестве административной единицы Лопские погосты появились в конце XV в. во время правления Ивана III. Иногда эту территорию называли также новгородской Лапландией, и она включала в себя семь Лопских погостов: Линдозерский, Семчезерский, Селецкий, Паданский고 Ругозерский, Шуезерский и Панозерский [История Карелии: 312].

Более ранний «Лопский погост» мог существовать некогда и в южной части современного Олонецкого района, о чем свидетельствуют, например, данные топонимии. Считается, что первые погосты на юге Республики Карелия появились к середине XIII в. на землях средневековых вепсов - в Посвирье и на Олонце, а также у русских и вепсских крестьян-переселенцев на Заонежском полуострове. Так, исследование текста Обонежского ряда и летописных сведений того времени показало, что налог (десятина) с погоста на Олонце стал поступать Дому Святой Софии в Новгород с конца 1250-х годов, когда эти земли были отданы республикой новгородскому князю в кормление [Жуков 2000: 44].

Между городом Олонец и деревней Baтчелицы (кар. Vuaččilu) Рыпушкальского с/с на не заливаемом во время разлива реки Олонки ${ }^{4}$ месте находились еще в середине XX в. километровый участок нетронутого леса и старое кладбище. Данная территория носила в карельской среде название Lapinpogostu, букв. «лопский/лопарский погост» [НТА]. Возможно, именно здесь могло располагаться некогда поселение Олонец, впервые упомянутое в 1228 г. в приписке к Уставу новгородского князя Святослава Ольговича. Отэтнонимическое название может тем самым свидетельствовать о том, что первонасельниками окрестностей Олонца, вероятно, были именно саамы-лопари, населявшие в тот период окрестности современного города.

Приведенные выше сведения дают возможность предположить, что до прихода прибалтийских финнов (вепсов) в пределах современного Олонца мог находиться так называемый саамский «зимний погост», который являлся определенной формой организации и сотрудничества нескольких родов / семейных групп саамского населения (ср. совр. саам. «зимняя деревня»). В их пользовании были «общинные» промысловые угодья, распределение и управление которыми происходило в зимнее время, когда члены родов собирались вместе для решения общих организационных и правовых вопросов. По мнению ряда исследователей, появление такой формы организации саамских родовых сообществ относится в разных

${ }^{3}$ В Карелии фиксируются отэтнонимические названия lappi и lappalaine, которые указывают, как правило, на население, проживающее на севере по отношению к говорящим, несмотря на то, что речь идет о (саамах или) том же карелоязычном населении [Бубрих 1947: 39-40]. Интересен при этом тот факт, что карелы бывшей Мяндусельской волости, а также некоторых деревень Паданской волости до сих пор используют в отношении себя самоназвание lappalaine (букв. 'саам-лопарь'), а также называют свой язык lapinkieli (букв. 'саамский язык').

4 Заметим, что и само название реки Олонеи (совр. Олонка, кар. Anuksenjogi) может быть саамским по происхождению, ср. прасаам. *ōlō 'паводковые воды' + топонимообразующий суффикс пс̌е̄, т. е. *⿻̄lōnče $\rightarrow$ Oлонеu. Этому, например, не противоречит расположение низовий реки в пределах Олонецкой равнины, которая в период проживания здесь саамского населения была, видимо, подвержена весенним паводкам. 
частях Фенноскандии к периоду Средневековья, а именно к 800-1150/1300 гг. нашей эры [Halinen 2011: 158; Carpelan 2003: 70 - 71]. Можно, таким образом, полагать, что освоение древними вепсами (прибалтийскими финнами) окрестностей Олонца не было, видимо, случайным, поскольку здесь мог находиться некий административный центр саамского населения северо-восточного Приладожья, рано попавший в сферу экономических и торговых интересов древних вепсов.

\section{Лексика саамского происхождения ${ }^{5}$}

На основании бытования саамской по происхождению топонимии можно говорить о том, что саамылопари населяли ранее всю территорию современной Карелии. В то же время письменных языковых памятников проживавших в Карелии саамов не зафиксировано. Исчезновение или смена языка местного автохтонного населения происходили по мере постепенного смещения языковой границы вследствие освоения прибалтийскими финнами все новых и новых территорий, начиная с конца Средних веков. На основании лингвистических данных можно с большой долей уверенности говорить о том, что часть древнесаамского населения Карелии могла быть ассимилирована прибалтийско-финскими новопоселенцами. Нельзя исключать, что в конце эпохи Средневековья в этом процессе приняло участие и славянское население Новгородских земель. Свидетельством этого являются заимствованные у саамов слова в местных говорах карельского, вепсского и русского языков. Они фиксируются, например, в большом количестве в местной географической лексике, а также в лексике фауны (ср. кар. čiekerö, kiekerö [KKS], pyc. кегора, тегора 'зимнее пастбище оленей' < *čieker 'тж.'; кар. pahta, puahto [KKS], pyc. naxта 'крутая (отвесная) скала; скалистая возвышенность, круча' < *pāktē 'скала'; кар. kuтpši [KKS], рус. кумжа [Дуров 2011: 198] 'озерный лосось, таймень небольшого размера'< *kuvčā/e 'таймень'; кар. тuržu [KKS], рус. морж 'морж' < *morše 'тж.'; кар. nuoska, nuoskie [KKS] 'влажный; сырой' < *ńnocke 'тж.', другие примеры см. [Kuzmin 2013: 99-102].

Иначе говоря, значительная часть заимствованных у саамов слов относится к промысловой терминологии, а также связана с особенностями северного ландшафта, которые отсутствовали на территории прежнего проживания новопоселенцев. Данный факт говорит о том, что они столкнулись на новоосвоенных территориях как с новыми для себя реалиями ведения промысловой деятельности (морской промысел, оленеводство), так и с новыми типами уже известных промыслов, таких как охота и рыболовство, в новых природных условиях. Например, названия многих беломорских рыб имеют прямые параллели в саамских говорах Кольского полуострова. Интересно также при этом, что позднее многие из них вошли в современный русский язык.

Таким образом, новая лексика не создавалась средствами своего языка, а напрямую заимствовалась у первонасельников региона - саамов-лопарей. Выше уже указывалось, что, по крайней мере, часть саамского населения Карелии была ассимилирована новопоселенцами, что явилось, в свою очередь, хорошей предпосылкой для сохранения традиционной саамской лексики в карельских и русских говорах населения региона. Кроме этого, часть лексики, без сомнения, была заимствована через межнациональные браки, а также в результате торговых отношений местного автохтонного и пришлого населения.

Можно отметить также, что бо́льшая часть фиксируемых у карел и русских слов известна прежде всего в северных говорах собственно-карельского наречия, а также в поморских говорах современного русскоязычного населения - иначе говоря, на территориях, проживание на которых лопарей документируется по историческим источникам начала Нового времени. В то же время немало саамских заимствований фиксируется и в южных частях Карелии, а также в вепсских и русских говорах северо-запада России, на территориях, расположенных достаточно далеко от ареала современного бытования саамского языка: ср. рус. арешник 'камень-голыш' [Окороков 2005: 369] < прасаам. *ārēe 'каменистое место' (> саамК ä'rešm) [Itkonen 2011: 16]; рус. чолиа 'пролив' [ПФГЛ: 84] < *čoalmē 'пролив'; кар. jok(k)oh, jokkohut 'звериная тропа, протоптанная в снегу; тропинка; путик' [KKS] < саамK čuahkas, čuegas 'зимник' [Itkonen 2011: 686]; рус. янга, янговина 'топкое место на болоте; окно на болоте; сырая ложбина' [Куликовский 1898: 142] < *jēnkē ‘болото'; кар. kenti, kenttä 'открытая ровная поляна или луг (с песчаной почвой)' [KKS], вепс. kend(äk) 'берег водоема, край болота' [СВЯ: 194], рус. кенда 'возвышенное травянистое место на болоте; бор на возвышенности с песчаной почвой' [Куликовский 1898: 35] < *kientē 'природный луг'; кар. korgo [KKS], рус. корга 'каменистая отмель; подводная скала' [Куликовский 1898: 40] < *kuorkō(j) 'отмель, риф, луда'; кар. kuotkuva [KKS], рус. коткуй '(узкий) перешеек' [НTA] < *kuotkō(j) ‘перешеек’; кар. kuržu ‘влажное буреломное место или овраг’ [KKS] < *korse ‘овраг, ложбина';

5 При написании данного раздела была использована следующая литература: [Aikio 2009; Itkonen 1986, 2011; Lehtiranta 1989; Nielsen 1979; Фасмер 1986]. 
кар. n'uoru [KKS], рус. нюра 'подводная отмель' [Куликовский 1898: 66] < *ńuore 'отмель';

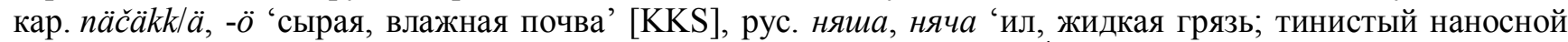

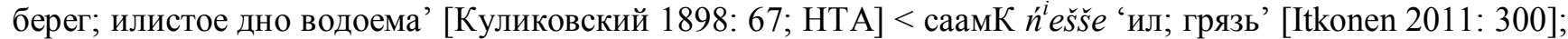
кар. иаје '(заросший) родник; жидкое болотистое место' [KKS] < *ājęk 'родник, ключ'; кар. роža 'залив' [Кузьмин 2020: 164] < *роаššó 'задний угол чума' > 'залив'; кар. ruopas [KKS], pyc. ponaкa, ponac 'груда или куча камней; ледяная глыба или затор' [Подвысоцкий 1885: 148] < *roape 'груда камней; скалистая возвышенность'; кар. tundurvuara [KKS], рус. тундра '(поросшая ягелем) возвышенность; вершина крупной возвышенности' [Подвысоцкий 1885: 186] < *tōnter 'возвышенность' (> саaмK tūndar [Itkonen 2011: 613]); кар. vuara, vuaru [KKS], рус. варака 'лесистая возвышенность' [Кузьмин 2020: 230] < *vārē 'лесистая возвышенность'; кар. alli, al l' 'eikka [KKS], рус. аллейка 'утка-морянка' [Подвысоцкий 1885: 1] < саамК allōōke 'утка-морянка' [Itkonen 2011: 11]; кар. čiekšo 'скопа' [KKS] < *čiekče 'скопа'; рус. чухарь 'глухарь' [Куликовский 1898: 134] < *ćukče 'глухарь' (> саамК с̌uhčč [Itkonen 2011: 958]); кар. kond'ii [KKS], вепс. kon 'd'i 'медведь' [СВЯ: 223] < *kuomče 'медведь'; кар. kuиkšo(i) [KKS], pус. кукша 'кукша' [Подвысоцкий 1885: 77] > *kuoksegke 'кукша'; кар. čole 'потроха рыбы; внутренности; кишки' [KKS] < *čoale 'кишка'; кар. с́ити 'что-либо с горкой; выше краев' [KKS] < *čome 'куча'; кар. с́иna [KKS], рус. чун(к)и 'кережа; (саамские) санки' [Дуров 2011: 440] < *'́опе̄ 'кережа; санки'; кар. с̌иra 'сторона, край, бок' $[\mathrm{KKS}]<$ *čorō 'бок, край'; кар. čurmuine 'небольшое количество чего-либо; крупица, частица' [KKS] < *čorme 'горсточка; пригоршня'; кар. kualua 'брести, пробираться' [KKS] < *kālē- 'брести, пробираться'; кар. nuoska 'влажный; сырой’ [KKS] < *nuocke 'тж.'; кар. ola (s) 'направляющий желобок (на нижней поверхности лыжи)' [KKS] < *oalē-s 'тж.'; кар. puoska, puosku 'мелюзга (грубо о ребенке)' [KKS] < *pиосke 'тж.'.

Все вышеперечисленное указывает на активные контакты в пределах рассматриваемой территории пришлого прибалтийско-финского и русского населения с местными саамами, результатом чего и явилась достаточно хорошая сохранность как саамского пласта топонимии, так и названий, которые косвенным образом могут указывать на саамов. Можно также полагать, что в результате этих контактов часть саамского населения вошла через процесс билингвизма в состав прибалтийских финнов и русских карельского Беломорья [Кузьмин 2016: 181-185] в связи со сменой этнического самосознания и языка.

\section{Топонимия саамского происхождения}

Топонимия играет важную роль в исследованиях языковой и ранней истории того или иного региона. Для этого есть несколько основных причин. Во-первых, древняя топонимия массово сохраняется со времени, о котором не имеется никаких других письменных источников. При этом географические названия, как мы знаем, нередко представляют собой рудименты языка/языков, на которых говорило древнее население изучаемой территории. Таким образом, топонимы являются ценным источником для реконструкции исторической лексики и антропонимии. Во-вторых, географические названия закрепляются и сохраняются именно на тех территориях, на которых они используются. Многие значительные по размеру, а также важные с точки зрения хозяйственного использования географические объекты были названы достаточно давно, а их названия используются нами и сегодня, несмотря на неоднократную смену населения и языков. Предпосылкой сохранения древней топонимии в таких случаях является естественный и поэтапный ход изменения языковой и этнической ситуации в регионе.

Итак, в сравнении с другими источниками преимущество топонимии состоит в том, что ее сохранилось достаточно много. Кроме этого, одни и те же топонимические типы повторяются в разных контекстах на разных территориях, и тем самым их связь с ранними языковыми формами можно подтвердить. Ареалы топонимных моделей с разными языковыми истоками отражают процесс формирования этноязыковой карты той или иной территории, в нашем случае - Карелии. Таким образом, топонимия является надежным и многоплановым источником при освещении целого ряда вопросов, касающихся происхождения поселений, миграций и границ расселения различных этнических групп. В ней находит отражение хозяйственная и промысловая деятельность населения, природа и ее ландшафтные особенности, пути передвижения, поселенческая структура, а также другая историко-культурная информация.

Зафиксированные в Карелии топонимы позволяют выявить, например, места раннего возможного проживания саамов-лопарей в южных частях исследуемого региона. Ранее уже было отмечено, что саамской древней формой локального общинного сообщества являлась «(зимняя) деревня», или саам. siida (саамH) [SSS: 203] < *sijte. Она объединяла несколько семей или родов, у которых была общая территория проживания и природопользования. Девять месяцев в году каждая семья занималась промыслами на выделенной ей общиной территории, а три зимних месяца они проживали в сийде [Vilkuna 1971: 201—236]. Можно осторожно предположить, что о такой форме общинного (коллективного) проживания саамского 
населения в Карелии свидетельствуют такие топонимы, как Siidniemi ${ }^{6}$ (деревня, Святозерская волость) и Siidarvi (озеро, Янгозеро, Поросозерская волость). Топонимы с атрибутивной частью $\breve{S i}(i) d$ - фиксируются и в топонимии вепсов в Ленинградской области, и они, возможно, примыкают к группе рассматриваемых названий, зафиксированных в Карелии: ср. Šid’järv (рус. Сидозеро) (бассейн Капши, Ленинградская область), Šid’järv (рус. Шидозеро) (бассейн Лиди, Ленинградская область).

О саамском периоде в истории Карелии свидетельствуют и многие другие топонимы саамского происхождения. Необходимо все же заметить, что многие названия крупных гидрообъектов в топонимии республики остаются пока без надежной этимологии с точки зрения саамских языков. Данный факт является, видимо, свидетельством того, что этот пласт древней топонимии мог принадлежать населению, проживавшему здесь до освоения территории древними саамами. Наука на данный момент не выработала однозначного ответа на вопрос о принадлежности языка этого населения, однако следы его жизнедеятельности сегодня - это археологические находки досаамского периода в истории региона и, конечно же, топонимия. Кроме этого, следует помнить, что язык саамского населения Карелии, особенно ее южных частей, не является идентичным современным саамским языкам северной Фенноскандии, и тем самым часть затемненных названий географических объектов все же может относиться к незасвидетельствованному языку древних саамов-лопарей, проживавших на территории современной Карелии, особенно в ее южных частях.

В самих саамских языках сегодня фиксируется значительное количество слов, для которых не обнаружено никаких убедительных финно-угорских языковых параллелей. Среди них, например, geađgi 'камень', njárga 'мыс', ája 'родник', bákti ‘скала', roavvi 'выгоревшая земля', vuоtna 'фьорд, вытянутый по форме залив', gáisa ‘возвышенность со снежной вершиной (летом)', lismi 'конец порога', leakšá ‘лесистая долина', lu 'smm 'исток реки', suotnju 'крупное болото', njálla 'песец', тоrša 'морж’ [Saarikivi 2011: 104-105]. Речь, таким образом, идет о языковом субстрате, который был усвоен древними саамами от более раннего автохтонного населения. Другими словами, предки современного саамского населения, продвигаясь на север, ассимилировали проживавшее здесь ранее палеоевропейское население Северной Фенноскандии, происхождение которого до сих пор спорно. Однако, как уже было отмечено выше, следы его фиксируются в археологических находках. Возможно, что массовое ДНК-тестирование населения северо-восточных частей Европы прольет в будущем свет на эту проблему.

Следы языка этого населения фиксируются и в топонимии. Например, среди саамских слов субстратного характера можно видеть большое число географических терминов, которые сегодня широко известны в топонимии разных диалектных зон саамского языка. Часть из них представлена также в географических названиях современной Карелии и сопредельных территорий. Таким образом, ареал распространения подобных языковых элементов в топонимии отражает ареал расселения древнесаамского населения, который, например, не распространяется далеко на восток и юго-восток, на территорию современных Архангельской и Вологодской областей.

В карельской топонимии есть большое количество названий, которые остаются сейчас без надежной прибалтийско-финской или саамской этимологии. К таким затемненным топонимическим типам относятся, например, многие лимнонимы, или названия озер, ср. Tuoppajärvi, Kuittijärvi, N’uokkijärvi (N’uokku-) и др. Отметим также, что среди тридцати самых крупных озер Карелии только три названия имеют сегодня прибалтийско-финский источник: Himol'anjärvi (рус. Гимольское озеро, Поросозерская волость, ранее озеро *Jongu), Roukkulanjärvi (Ровкульское озеро, Ребольская волость, ранее *Enängi) и, видимо, Luadokka, или Ладожское озеро [Муллонен 2012а: 11]. Названия же целого ряда других остаются до сих пор без надежной этимологии. Это распространяется и на названия рек.

В то же время среди названий крупных озер есть и такие, которые можно достаточно легко объяснить с точки зрения саамского или прасаамского языков. Например, без особых проблем можно восстановить саамскую праформу для второго по величине озера Европы - Онежского, ср. вепс. Änine, кар. Iänizjärvi < *ēnē 'большой' [Муллонен 2002: 281], а также для Выгозера (кар. Uikujärvi, Vuikkajärvi), в названии которого воспроизводится наименование реки Выг, которое, в свою очередь, может восходить к именованию порога *Vuikakoski < *veke 'сила; сильный, мощный' или *veke 'с сильным течением'

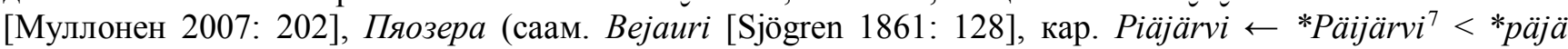

\footnotetext{
${ }^{6}$ К этой группе могут относиться порог Siidoikoski < *Siidakoski (Куйтежа, Неккульская волость), озеро Siidarvi < *Siidajärvi (Янгозеро, Поросозерская волость), болото Cидосуо < *Siidasuo (Лужма, Ребольская волость), (?) озеро Cuтозеро < *Siidajärvi (Вожмогора, Петровский Ям), а также, возможно, озеро Сигозеро в бывшей Коткозерской волости, название которого фиксируется в ревизских сказках 1782 и 1834 гг. в т. ч. в форме Cuдозеро < *Siidajärvi [РC 1782, 1834].

${ }^{7}$ Ср. крупный залив озера Пяозера с названием Päilakši
} 
‘верхний’) и Сямозера (кар. Siämäjärvi) < прасаам. *sāmē < *š̈̈mä 'саам’ (> фин. häme-). Относительно последнего И. Муллонен отмечает, что при некоторых спорных моментах данная этимология привлекает тем, что в ней отражается универсальная для топонимии ситуация появления отэтнонимных географических названий на границах расселения этносов и этнических групп. В данном случае можно предполагать, что Сямозеро было пограничным водоемом уже на этапе саамского освоения региона [Мамонтова, Муллонен 2008: 26-27]. Интересно при этом, что Сямозерье и сегодня является пограничным регионом на диалектной карте Карелии, гранича на востоке с говорами людиковского наречия, а на севере с собственно-карельским языковым ареалом.

Наибольшее количество саамских по происхождению названий фиксируется в средней и северной Карелии, где известно о проживании саамского населения по документам XVI-XIX вв. Но и в более южных районах республики фиксируется немало названий, которые являются саамским наследием в топонимии. Можно, например, отметить, что большинство карелоязычных названий бывших волостей имеет доприбалтийско-финские истоки: ср. Videle (рус. Buдлица), Vieljärvi (рус. Beдлозеро) < *vitel- (неизвестного происхождения), Kotkadjärvi (рус. Коткозеро) < прасаам. *kuotkō(j) 'перешеек', Kuиjärvi (док. Кукозеро, Гулкозеро) [ПКОП: 271] < прасаам. *kukkē 'длинный, долгий', Vuohtajärvi (рус. Boxmозеро) < прасаам. *ukti 'путь, дорога', Munjärvi (рус. Мунозеро) (неизвестного происхождения), Kontupohja (pус. Кондопога) < ? прасаам. *kontē 'дикий олень', Šиоји (рус. Шуя) < ? прасаам. *s'ojä (саам. čuoddjá [Mattus 2010: 15]) 'длинный узкий залив, в который впадает крупная река', Siämäjärvi (рус. Сямозеро) (прасаам *sāmē ‘саам, лопарь').

В то же время названия карелозычных приходов финской Карелии, за исключением самого северного прихода Иломантси (кар. Il'manči) ${ }^{8}$, имеют уже прибалтийско-финские истоки, cp. Salmi, Imbilahti, Suistamo, Korbiselgä, Suojärvi, Sovanlahti. Данный факт, на наш взгляд, свидетельствует о том, что прибалтийско-финские поселения на данной территории имеют более долгую историю, чем в Республике Карелия. Однако и в финляндской Карелии фиксируется немало названий, которые появились еще в саамский период истории региона. Некоторое количество саамов проживало здесь, на широте Сямозера, еще в первой половине XVII в. Известен, например, случай, когда один из представителей этого этноса женился на девушке из района Тулмозера [Korhonen 1938: 63].

Отметим здесь, что многие из представленных в топонимии Карелии топооснов саамского происхождения (напр., čolm-, el-, jang-, jaur-, kuk-/kukas-; топонимические примеры см. [Kuzmin 2013: 107-113]) фиксируются на обширной территории от Кольского полуострова и по крайней мере до Белого озера на юге, а также до Северной Двины на востоке. Важно также, что эти топоосновы восходят к общей для прибалтийских финнов и саамов праязыковой лексике. Таким образом, обширный ареал бытования этих элементов в топонимии может указывать на территорию проживания на северо-западе России населения, которое говорило некогда на едином древнем праязыке9.

Возможно, что память о саамском населении в южных частях Карелии хранят также названия с отэтнонимической атрибутивной частью Lapin-/Lappi- ${ }^{10}$ (карел. lappi/lappalaini 'саам, лопарь' [KKS]): yz. Lapinniittu (Святозеро), бол. Lapinsuo (Мошничье), оз. Lapind'ärvi (Михайловское), оз. Lapinlambi (Курганова Сельга), o. Lapinsuari (Руга), ? зал. Lappilahti (Кукойвара), бол. Lapinsuo (Ильинское) и др.

С другой стороны, очевидно, что язык саамского населения южной Карелии не был идентичным современным саамским языкам и, видимо, мог в значительной степени отличаться от них. Топонимические

\footnotetext{
${ }^{8}$ О происхождении см. ниже.

${ }^{9}$ Распад единой прибалтийско-финско-саамской языковой общности произошел приблизительно на рубеже бронзового и железного веков, или за 500-600 лет до н. э.; возможно, несколько позже.

${ }^{10}$ Свидетельствами древний промысловой традиции являются в Карелии географические объекты с названиями Lapinpačaš (букв. 'лопарский столб'), которые в конце XIX в. нередко фиксировались в местах рыбной ловли в Средней Карелии. Аналогичные деревянные столбы в окрестностях охотничьих и рыболовных угодий встречались в XIX в. и в северо-восточной Финляндии. Финское население считало их «богами» саамов, которые раньше здесь проживали. Согласно записанным устным рассказам, отправляясь на промыслы, саамы обещали установить столбсейд или вырезать на дереве образ (лик) «бога» в случае, если охота или рыбалка окажется удачной. Известно также, что эти деревянные столбики заменяли саамам каменные сейды, и им поклонялись во время промыслов. При этом они часто высекались в форме человеческой головы [Krohn 1894: 77; Leppäaho 1935: 38; Конкка 2013: 22 - 33, 46 - 48].

В данном контексте стоит, видимо, упомянуть, что в 1563 г. в Важенском погосте в окрестностях современного села Михайловское фиксировалась деревня над Бесовою головой на Бесовом ручью [ПКОП: 86] (совр. рус. Гижино, кар. Hidniemi). Можно предположить, что это название указывает на описанную выше саамскую традицию в северных частях Финляндии, где зафиксировано немало столбов-сейдов (фин. kalajumala или keripää) вблизи хороших тоней, особенно в бассейне реки Кемийоки [Elo, Seppälä 2011: 23, 27].
} 


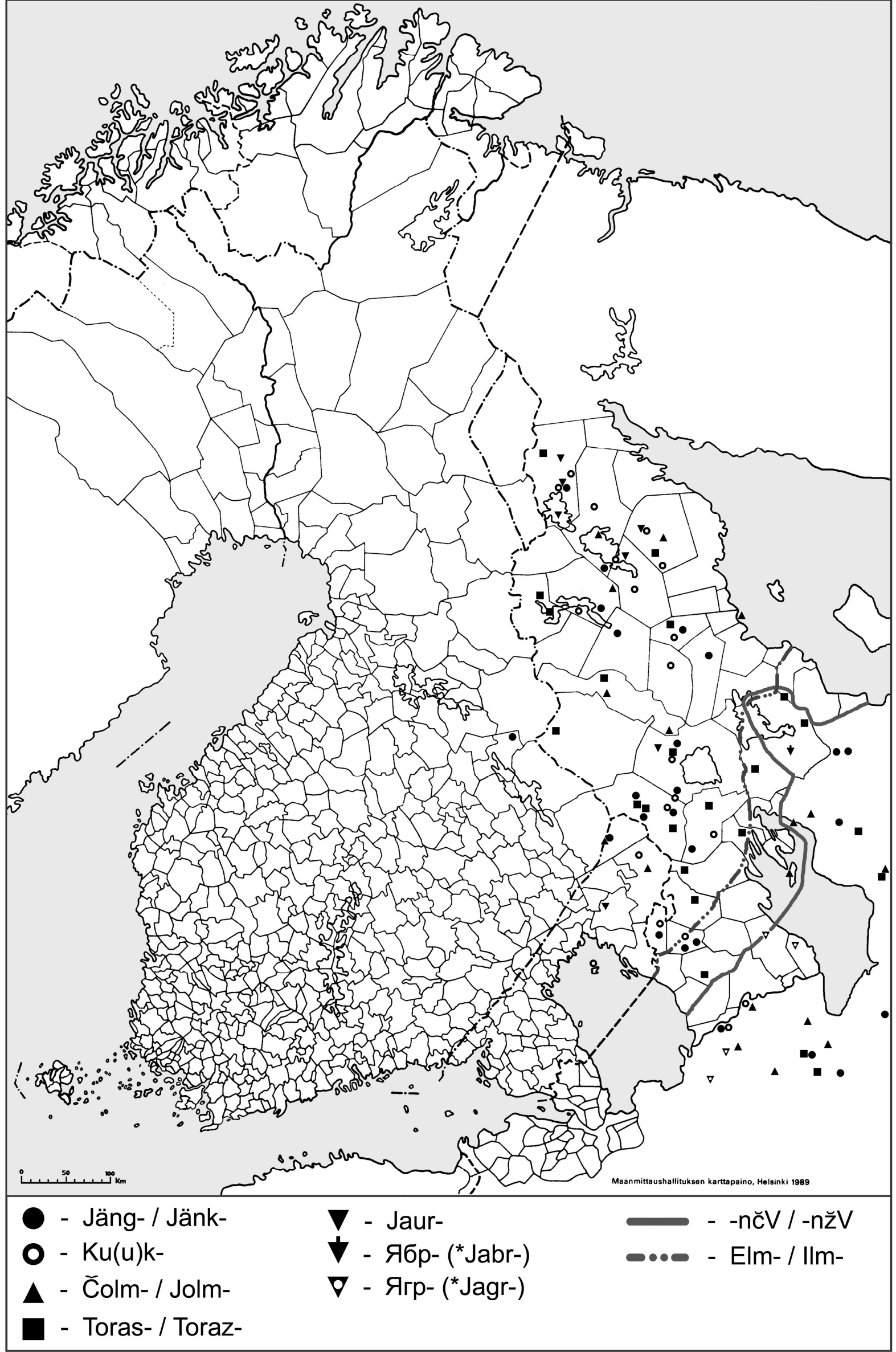

Карта-схема 1. (Пра)саамские топонимные типы на территории Карелии 
данные также свидетельствуют, что и на самой территории современной Карелии формы древнесаамского языка не были едиными. В разных частях исследуемого региона топонимические и лексические параллели для «докарельских» географических названий обнаруживаются на территории бытования разных саамских языков. В данном контексте можно все же отметить, что часть лексических элементов, имеющих широкое распространение в современной саамской топонимии, фиксируется, прежде всего, в северной и средней Карелии. На более южных территориях, а также в восточных частях Карелии топонимия свидетельствует о том, что здесь некогда бытовали отличающиеся от современных формы древнесаамского языка.

Так, показательным примером может служить зафиксированный в топонимии элемент, за которым стоит прасаамский диминутивный суффикс *-ńće. В Карелии бытуют два генетически близких варианта этого суффикса: -nčV $(*-n ́ c ̌ e)$ и -нжа/-нза (*-ńdźe), из которых первый представлен как в карельской, так и в русскоязычной топонимии, второй - только среди русскоязычных названий в южных частях Обонежья и в юго-восточной части Карелии, включая восточные части современной Архангельской области на границе с современной Карелией (ср. река *Ōlōnčē (рус. Олонеи), поселение Povenča (рус. Повенеи) // остров Веренжа (Водлозеро, Пудож), река Роменьжа (Воренжа, Сумозеро)) [НTA].

Данные факты свидетельствуют о явной ареальной оппозиции $-n c ̌ l l-n z ̌ V$, за которой скрываются разные этноязыковые истоки населения, давшего названия географическим объектам. В этом случае форма древнесаамского (субстратного) языка в восточной и юго-восточной части Обонежья отличалась, судя по распространению рассматриваемого элемента, от субстратного языка, бытовавшего в западной и северо-западной частях Карелии. Границей этих двух древних диалектов была, видимо, на определенном этапе условная линия: река Свирь - Онежское озеро - Выгозеро - река Выг - побережье Белого моря. К северу и западу от этой границы использовалась форма с формантом -nč $V$, в то время как на востоке и юго-востоке - элемент $-n z \check{V}, \mathrm{cp}$. на соседствующих «пограничных» территориях: озеро Пелончозеро в Выгозерье и часть реки с названием Воренжа в Сумозерье, а также однокоренные атрибутивные части в названии острова Ilmančisuari в бывшей Поросозерской волости и реки Илеменза $(*$ Ilemenza) в Сумозерье [HТА].

Этот же суффиксальный тип можно выделить в карелоязычной и финноязычной субстратной топонимии современной Финляндии: ср. озеро Il'mančinjärvi (Иломантси), река Kuvansi(njoki) (Ёройнен), озеро Kuvansi (Леппявирта), озеро Syvänsi (Яппиля) [NA]. Данный факт свидетельствует о том, что в западных частях современной Карелии и в восточной Финляндии бытовал некогда один общий саамский язык или, по крайней мере, достаточно близкие его диалекты.

Далее в топонимии Карелии присутствует два топонимических типа, которые также являются показательными с точки зрения языковой истории саамов Карелии, - Ilm- и Elm-. Речь в данном случае идет о двух фонетических вариантах одной и той же лексемы, которая восходит к общей прасаамской основе *elme- 'самый верхний'. Фонетический облик указанных выше элементов дает возможность интерпретировать ареал их распространения в свете разных этапов развития древнесаамского языка. Границей этих типов является опять же условная линия Иломантси - Тулмозеро - Ведлозеро - Сямозеро - северо-западная часть Онежского озера - восточная часть Выгозерья. На ее северной стороне в топонимии фиксируется атрибутивный элемент Elm- (ср. ручей El'mičoja (Эльмитозеро, Вохтозеро)), в то время как на южной выступают названия на Ilm- (cp. болото Ilmahansuo (Самбатукса, Неккула)). К ареалу последнего из упомянутых типов примыкает ряд топонимов за пределами Карелии, например в Ленинградской и в восточной части Архангельской области. Одно название рассматриваемого типа - возвышенность Ilmačinvuara - известно также к северу от вышеуказанной линии — в деревне Янгозеро бывшей Поросозерской волости.

Таким образом, на основании качества начального гласного можно говорить также о двух диалектах древнесаамского языка, из которых форма Elm- ближе к поздней прасаамской, а форма Ilm- — к ранней прасаамской языковой форме [Муллонен 2018: 20-21]. Тем не менее данный вопрос требует дальнейшего исследования, поскольку названия на $E l m$ - фиксируются также достаточно далеко от современной Карелии, например в Архангельской и Вологодской областях (ср. [Saarikivi 2006: 196-197]).

\section{Вепсы}

На смену саамам в Обонежье приходит прибалтийско-финское население, и первенство здесь принадлежало древним вепсам, которые начали осваивать территории к северу от Присвирья в самом конце I тыс. - в первые века II тыс. н. э.

Свидетельством проживания древневепсского населения в южных частях Олонецкой Карелии в конце эпохи викингов может являться курганная культура, фиксируемая на берегах рек Видлицы, Тулоксы, 
Олонки ${ }^{11}$ и датируемая периодом X-XIII вв. Фиксируемые здесь погребальные памятники аналогичны курганам юго-восточного Приладожья, и тем самым данный факт позволяет говорить о переселении на Олонецкую равнину населения с более южных территорий ${ }^{12}$. Формирование самого древневепсского населения происходило в южном Приладожье, а наиболее ранние курганы появляются здесь во второй половине IX в. [Кочкуркина 1996: 290]. Вскоре после этого древневепсское население осваивает бассейн Паши и нижнее течение Ояти, а также продолжает продвигаться все дальше на север и северо-запад. Поселенческая деятельность древних вепсов подтверждается также раскопками курганов, проводившимися в 1990-х гг. на Заонежском полуострове и на северном побережье Онежского озера. И в данном случае археологами обнаружены явные связи уже территории Заонежья с курганной культурой юго-восточного Приладожья [Кочкуркина 2019: 288-289; Saksa 1998: 120, 124]. В то же время появление вепсского населения в Заонежье относится все же к более позднему историческому периоду, чем на Олонецкой равнине.

Далее можно отметить, что, согласно археологическим данным, в эпоху викингов у древних «вепсов» было три основных поселенческих центра: долина реки Шексны к югу от Белого озера, долина реки Суды к юго-западу от Белого озера и долины рек Ояти, Сяси и Паши в юго-восточном Приладожье [Кочкуркина 2006: 182-186]. Однако в соответствии с современными ономастическими представлениями применительно ко всем вышеуказанным центрам вряд ли можно говорить о вепсах как прибалтийско-финском населении. Речь в данном случае идет скорее о веси как древнем населении Белозерья, которое в языковом отношении сближалось с населением Поволжья или с тем населением, которое можно характеризовать как носителей западно-уральского праязыка, общего предка саамских, прибалтийских-финских и мордовских языков. Судя по топонимии, в Белозерье выявляется очень мощный неприбалтийско-финский пласт, в то время как прибалтийско-финский относительно слаб и представлен в значительной степени в северном и северо-западном Белозерье, при этом поздними топонимическими типами. Таким образом, «весь белозерская» русских летописей может быть тем древним населением, на которое «наложились» прибалтийские финны, продвинувшиеся из Поволховья на восток и юго-восток [Захарова, Макарова, Муллонен 2016; Муллонен 2019: 306, 312; Муллонен 2012б: 18; Saarikivi 2006].

В процессе колонизации древними вепсами Ладожско-Онежского межозерья их этнический ареал к XV в. охватил обширные земли, включающие территорию современного расселения людиков и ливвиков, сформировавшихся в результате этнического взаимодействия вепсов и пришлых «корельских выходцев» из северного и северо-западного Приладожья [Жуков 2008: 42-43]. В основе двух карельских наречий, ливвиковского и людиковского, хорошо просматривается вепсская субстратная языковая основа, при этом именно у людиков сохранился значительный вепсский элемент на всех уровнях языка.

Подтверждение этому мы можем видеть, например, в этнонимике Карелии, поскольку карелыливвики (liygi(läine), livviköi [CКЯ: 188]) и карелы-людики (lyydi, lyydikoi [LMS: 221]), а также северные или прионежские вепсы и часть носителей средневепсского диалекта (вепс. lydinik/lydilain'e [СВЯ: 304]) используют в отношении себя один и тот же этноним lyydi (< pус. люди). Данный факт, по мнению И. И. Муллонен, дает основание полагать, что этноним lyydi распространился в первые века II тыс. по Свири вместе с новгородским освоением и использовался для именования местных вепсов, которые в то время были основным населением как южного, так и северного Присвирья. В дальнейшем, в ходе карельского продвижения из северо-западного Приладожья в Онежско-Ладожское межозерье, вепсское население северного Присвирья постепенно ассимилировалось карелами, и данный этноним стал обозначать здесь карелизированных вепсов — ливвиков и людиков [Муллонен 2011: 229—230].

Ливвиковское наречие карельского языка бытовало ранее также в финляндской Приграничной Карелии (фин. Raja-Karjala), в частности, на территории бывших приходов Салми и Импилахти, в южной части Суйстамо, а также в восточной части прихода Суоярви. Лексическая база суоярвского говора, в отличие от других говоров собственно-карельского наречия, во многом близка ливвиковским говорам соседней Сямозерской волости, а языковое взаимодействие с его носителями не вызывало раньше никаких трудностей. На наш взгляд, можно полагать, что ливвиковское население бывшего Шуезерского погоста Корельского уезда перешло на собственно-карельский диалект относительно поздно, видимо, на протяжении XVII в., когда сюда после заключения Столбовского мирного договора стало переселяться собственно-карельское население из западных частей бывшего Карельского уезда, оставшееся с массовым приходом финнов-лютеран в меньшинстве, ср. [Laasonen 2005: 111].

\footnotetext{
${ }^{11}$ Kap. Anuksenjogi. Необходимо отметить, что в историческом труде De origine actibusque Getarum («Происхождение и деяния готов»), написанном Иорданом около 551 г., есть место, которое ряд исследователей склонно считать первым упоминанием о вепсах: cp. «thiudos: Inaunxis Vasinabroncas Merens Mordens Imniscaris...» (перевод: [завоевал] «народы: в Олонце vas [? *ves' = вепсы], ? в Абронкасе мерю, мордву в Мещере») [Напольских 2006: 100].

12 Важное значение в освоении территорий к северу от Свири имела для древних вепсов река Важинка (кар. Vuažn'and'ogi) [Муллонен 2002: 289] (см. ниже).
} 


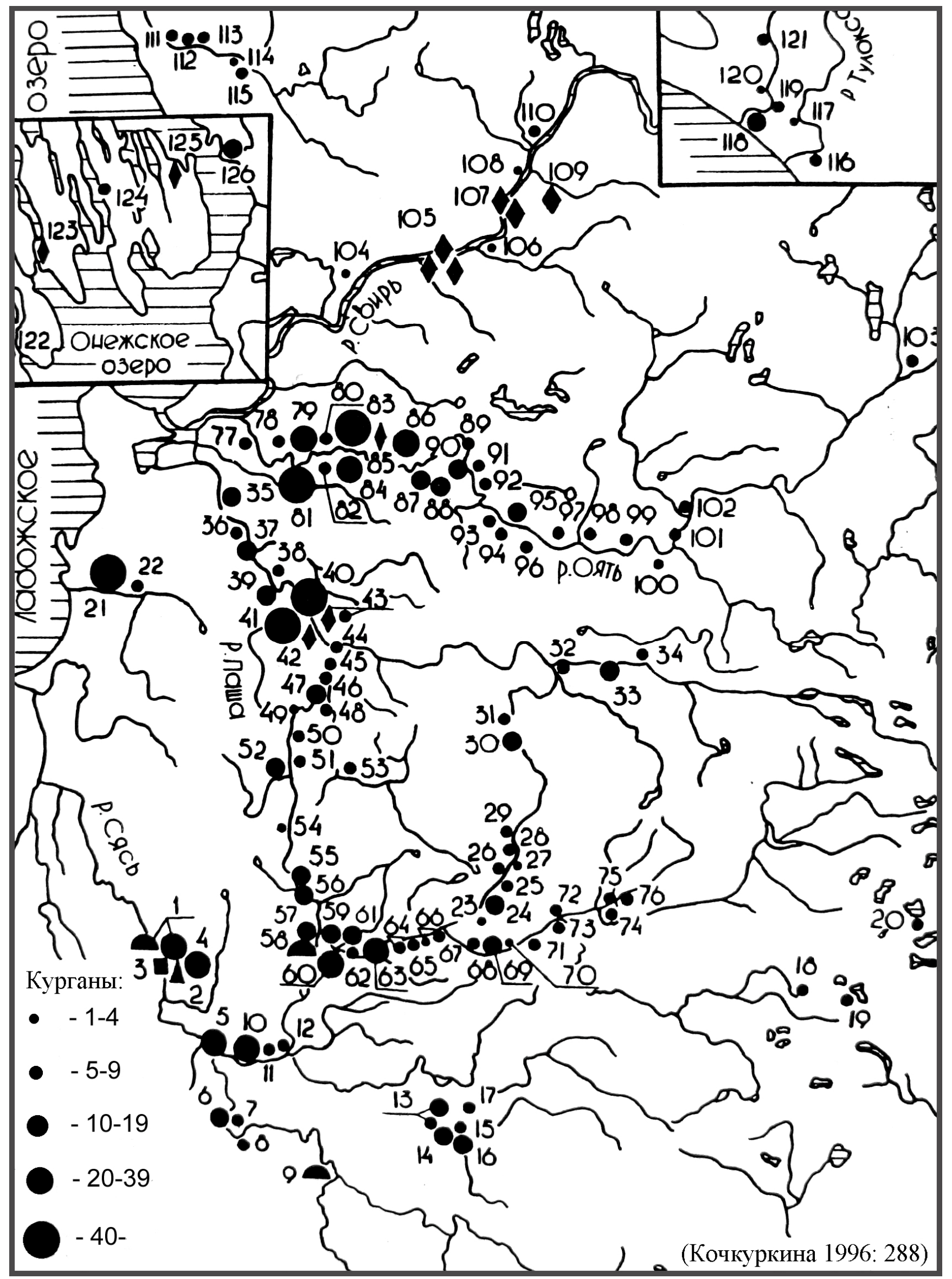

Карта-схема 2. Курганная культура в Присвирье и южной Карелии 
Распространение ливвиковского наречия в финляндской Приграничной Карелии свидетельствует о том, что древние вепсы населяли в первой половине второго тысячелетия достаточно обширную территорию, доходившую на западе до прихода Импилахти (совр. Питкярантский район в 40 км к востоку от Сортавалы). Бытование подобного ареала может объясняться экобиологическими и географическими особенностями местности. Древние вепсы, являясь земледельцами, освоили прежде всего те территории, которые были пригодны для сельского хозяйства, в частности, для разработки подсеки. Именно на бывших ливвиковских территориях Финляндии, включая приход Импилахти, распространен тип почв, который близок по качеству и составу почвам юго-восточного Приладожья (О. А. Яровой, устное сообщение, см. также [Муллонен 2012б]). Таким образом, широта расселения вепсского населения может быть увязана с практикуемым им образом ведения сельского хозяйства, которое было ориентировано на разработку подсеки. Видимо, именно по этой причине современные северовепсские земли в Прионежье были заселены вепсами в более позднее время, чем Олонецкая равнина и прилегающая к ней с запада территория Приграничной Карелии. Скалистый характер побережья Онежского озера, водораздельные болота, а также менее плодородные почвы хуже подходили вепсам для ведения именно сельского хозяйства. В. В. Пименов, например, отмечал, что вепсские поселения на юго-западном побережье Онежского озера появились не ранее XIV в. [Пименов 1965].

Северной границей распространения средневекового вепсского населения в Карелии была северная зона распространения среднетаежных лесов. Таким образом, и в данном случае мы можем видеть, что природная граница, отделяющая территорию с более благоприятными условиями для ведения земледелия в северном климате, преобразовалась в границу этническую. Данный факт свидетельствует о том, что распространение древневепсского населения на север также было обусловлено именно природноклиматическими факторами, и подтверждает тем самым мысль о сельскохозяйственной направленности жизнедеятельности средневековых вепсов [Муллонен 2012б: 22].

Данный вывод можно подкрепить распространением в топонимии Карелии топооснов Niini- (кар. niini 'липа' [KKS]), Lehmus- (кар. lehmus 'липа' [LMS: 196]) и Лип(овый)- (ср. остров Niinisuari, поле Lehmuspeldo, возвышенность Нинисельга, Липручей, Липовое поле и др.) [НTА]. Перечисленные топоосновы отражают естественный природный ареал распространения в Карелии липы, которая произрастает на достаточно плодородных почвах, а в местах ее произрастания нередко находятся сельскохозяйственные угодья. Липа распространена в Карелии к югу от условной линии Вяртсиля - Сямозерье - северная часть Заонежского полуострова. В восточных частях Карелии она встречается спорадически в бассейнах рек Водлы и Колоды в Пудожском районе [Кравченко 2007: 135]. Практически идентичными по распространению в северном направлении являются ареалы ряда вепсских топонимических моделей. Таким образом, существовавшие природные условия определили ареал продвижения вепсов на север, что, в свою очередь, свидетельствует о большой роли практикуемого древними вепсами сельского хозяйства в освоении Олонецкого перешейка и восточного Обонежья [Муллонен 2011: 231-232, 238]. Можно здесь также отметить, что на севере освоенного вепсами ареала проходит диалектная граница собственно-карельского наречия с карелами-ливвиками и карелами-людиками. Известно, что появлению языковых и культурных границ нередко способствуют именно ландшафтно-географические и природноклиматические факторы, что полностью подтверждается в данном конкретном случае.

Выше уже было отмечено, что на проживание в южных частях Карелии древневепсского населения указывают и данные этнонимики, в данном случае топонимы с атрибутивной частью Vepsän- (букв. 'вепс, вепсский'): cp. Vepsänтиа, -polvi (Титнаволок, Вохтозеро), Vepsänvиara, -lambi (Покровское, Мяндусельга), Vepsälambi (Сельги, Паданы), Вепсино (Вирма, Беломорье), Vepsniem' = Bencнаволок, Bencoзеро, Вепсгуба (Кондопога) [НТА]. Собственно-карельское население бывших Паданской и Поросозерской волостей называет проживающих южнее людиков именно веnсами (кар. vepsä ${ }^{13}$, vepsäläne), что, без

${ }^{13}$ Названия на Vepsä- встречаются также на севере в Беломорской Карелии, ср. Vepsävиаra (Хижезеро, Юшкоз.) и Vepsäjärvi (Боярская, Вычет.) [НТА]. Оба топонима зафиксированы достаточно далеко от территории средневекового проживания вепсского населения, и, таким образом, вопрос о принадлежности носителей фамилии/ прозвища Vepsä к древним вепсам остается пока открытым. Другими словами, в основе названий фиксируются, видимо, антропонимы, но без привязки к этническому происхождению их носителей. В то же время нельзя исключать, что носитель рассматриваемого прозвища / родовой фамилии мог быть родом именно из южных частей современной Карелии. Можно также упомянуть, что одно из преданий, записанных Энгельбергом в начале ХХ в. в юго-западной части Беломорской Карелии, повествует о том, что один из родов деревни Аконлакша переселился сюда «с территории вепсов» [Engelberg 1912: 101]. Речь, видимо, может идти о роде Мелентьевых, одним из наиболее ранних предков которого был Мелентиа Вепсяляйнен [Kuzmin 2015: 158], проживавший ранее на территории современной Финляндии в Кайнуу. Там же фиксируется и название озера Vepsänjärvi [NA]. 
сомнения, может быть указанием на ранее проживавших здесь представителей средневековых вепсов, которые со временем карелизировались. Названия на Vepsä-, Vepso-, Vepsu- ${ }^{14}$ фиксируются также в Финляндии, прежде всего в ее юго-восточной и восточной частях. Они присутствуют также в карелоязычной топонимии Приграничной Карелии: ср. Vepsäjärvi (упом. 1621), Vepsonselgy (приход Салми) [NA]. В Финляндии фиксируется также фамилия Vepsä(läinen), которая характеризуется главным образом восточным ареалом бытования. Финляндский этнограф Нийло Валонен предполагал в свое время, что данный факт может свидетельствовать о возможном проживании древневепсского населения в юговосточных и восточных частях Финляндии [Valonen 1980: 72, 74]. Если предположение о распространении ареала средневековых вепсов вплоть до территории прихода Импилахти верно (см. выше), то можно полагать, что подобные наименования в восточной Финляндии могут указывать на достаточно ранних переселенцев, например, из северного Приладожья.

Данные, касающиеся территории Карелии, содержащиеся в средневековых письменных документах, «отмечают» невозможность четкого определения границы - «межи» Шуйского погоста - основной территории формирования карелов-людиков. Главной причиной было то, что шуяне Шуйского, святозерцы Важинского, кижане-кондопожане Кижского погостов (предки современных северных людиков) и сямозерцы Олонецкого погоста (будущие ливвики) возделывали подсеку по всей чисто условной линии административного размежевания этих погостов. Эти факты позволили историку А. Ю. Жукову предположить, что «такое "нарушение межи" на Шуе стало возможным лишь по той причине, что от Олонца до Кондопоги на местах сохранялись кровнородственные и шире - племенные связи местных жителей как прямых потомков древних вепсов: самые северные родовые земли веси протянулись широкой полосой от Сямозерья на западе, через Святозеро и реку Важинку на юге, реку Шую в центре и до северных заливов Онежского озера на востоке» [Жуков 2008: 43].

О присутствии древних вепсов в южных частях Карелии свидетельствует явный языковой субстрат в ливвиковских и людиковских наречиях карельского языка. В то же время в топонимии региона выявляется крайне мало топонимных типов, которые бытовали в период проживания здесь вепсов. Главной причиной этого является тот факт, что ареалы распространения топонимических моделей близкородственных языков далеко не всегда являются надежными. В данном случае лексика, используемая в образовании топонимов, восходит в ливвиковских и людиковских наречиях, а также в вепсском языке к общей для этих диалектных зон лексической основе. Тем самым поиск вепсских дифференцирующих элементов в топонимии региона в значительной степени затруднен. Задачей исследователя становится выявление таких названий-меток, или критериев идентификации, с помощью которых все же можно было бы

Можно также отметить, что в 1920-х гг. и ранее жители бывшего Линдозерского погоста (село Линдозеро) называли землями вепсов (кар. Vepsä) территорию современного Кондопожского района, где и сейчас проживают карелы-людики. При этом отмечается, что территория проживания прионежских вепсов в начале 20-х гг. ХХ столетия не относилась к территории, называемой карелами Vepsä [NA]. Жители финляндской Приграничной Карелии именовали землями вепсов находившиеся к востоку от них северные части бывшей Сямозерской волости, другими словами, куст ливвиковских вохтозерских деревень [KKS]. В то же время для жителей прихода Суоярви, а также для сямозерских карел бывшая Поросозерская волость считалась уже «Лапландией» (кар. Lappi) [NA, KKS]. Taким образом, данный факт свидетельствует, что к моменту появления в среде приладожских карел географических понятий Lappi и Vepsä к востоку от северной части Корельского уезда (в частности, от бывшего Шуезерского погоста) начинались некогда земли лопарей и вепсов, границей которых являлась, видимо, современная диалектная граница двух наречий карельского языка - собственно-карельского и ливвиковского, проходящая к югу от реки Суна. На более восточных территориях границей Vepsä и Lappi являлась, судя по данным этнонимики, диалектная граница собственно-карел и карел-людиков. Тем самым речь может идти о XIV-XV вв., а возможно, и о еще более раннем периоде истории. Кроме этого, факт использования собственно-карелами в отношении будущих ливвиковских территорий географического термина Vepsä (букв. '(земли) вепсов') свидетельствует о том, что древние вепсы населяли ранее более обширную территорию, и именно их язык стал языковой основой будущих говоров ливвиковского наречия. Применительно к вышеуказанной территории речь идет о Сямозерском и Вохтозерском говорах. Таким образом, данные этнонимики проливают свет в том числе на систему расселения древних вепсов.

О более позднем вепсском населении может, видимо, свидетельствовать неофициальная карелоязычная фамилия Šokšu (Юксила, Рыпушкалица) [НТА], поскольку население южных частей Карелии использовало этноним šokšulani как для обозначения жителей Шокши, так и для обозначения прионежских вепсов в целом [KКS]. Жители Приграничной Карелии также отмечали, что приоятские и прионежские вепсы говорят на одном диалекте [NA].

${ }^{14}$ Финляндский языковед Рихо Грюнталь отмечает, что форма фамилии, а также топонимов на Vepsu в Финляндии может указывать на ее ливвиковское происхождение [Grünthal 1997: 101]. В то же время обращает на себя внимание тот факт, что большая часть подобных наименований фиксируется все же в западных частях Финляндии. 
разнести данные близкородственных топонимических систем и посредством этого выявить вепсский топонимический субстрат в ареале расселения карел-людиков и карел-ливвиков.

Целесообразно, например, использовать в качестве критерия топонимные модели, которые бытовали на той или иной территории ограниченное время, а их распространение можно отождествлять с проживанием на ней определенной этнической или языковой группы. В данном контексте показательным примером могут быть наименования крупных водных объектов с основой Pyhä- 'святой' в южных частях Карелии.

Финский историк С. Суванто заметил в свое время, что на территории Финляндии и Эстонии гидронимы с основой $P y h \ddot{a}$ - привязаны к древним, восходящим еще к железному веку родовым границам [Suvanto 1972: 54]. Предпринятый И. И. Муллонен анализ гидронимной модели на Pyhä- / Cвят- в Карелии также свидетельствует, что часть из таких гидронимов действительно привязана к старым границам. Исследовательница также отмечает, что этапы семантического развития слова $p y h a ̈$, закрепившегося в качестве гидронимной основы, свидетельствуют о том, что продвижение древних вепсов на север должно было произойти не позднее рубежа I-II тыс. н. э., или в период до вытеснения изначальной семантики ('граница' $\rightarrow$ 'святой') [Муллонен 2002: 155]. Таким образом, можно полагать, что название озера, а позднее волости Pyhäd'ärvi (рус. Святозеро) могло маркировать на рубеже тысячелетий северную границу древневепсского расселения в северном Присвирье. В дальнейшем, как мы уже знаем, эти же «святые межи» использовались в практике административно-территориального разграничения в Карелии в более позднее время.

Показательно при этом, что в топонимии озера Святозера фиксируется географическое название Siidniemi [HTA], в котором восстанавливается уже упомянутая выше саамская лексема *sijte '(зимняя) деревня'. Данный факт, как нам представляется, не является случайностью, и освоение древними вепсами окрестностей Святозера было предпринято в том числе и потому, что здесь мог находиться один из родоплеменных центров саамского населения, где происходило управление природными ресурсами северо-западного Обонежья и их распределение. Нельзя также исключать, что местные саамы могли уже тогда попасть в зависимость от средневековых вепсов, которые начали осваивать лопские земли на рубеже тысячелетий.

В ряде случаев используемая в топонимообразовании лексика также может быть критерием идентификации языка населения, которое некогда проживало в южных частях Карелии. Существенно при этом, чтобы подобная лексика фиксировалась только в одном из прибалтийско-финских языков и не встречалась в другом или, по крайней мере, бытовала в нем ограниченно. Так, вепсскими по происхождению могут считаться следующие атрибутивные элементы, фиксируемые в топонимии карел-ливвиков и карел-людиков: *Čuhak-/*Čuhuk- 'холм, горка' [Муллонен 1994: 56], Homžoman- (вепс. hongžom 'сосновый лес; сосняк') [ПФГЛ: 31], Kiehker- (вепс. kehker 'круглый’) [СВЯ: 191], Kuara- (вепс. kara 'залив’) [СВЯ: 179], Kukuoinhard' 'холм, возвышенность' [Муллонен 1994: 32], Palte- 'склон' [ПФГЛ: 70], Pehk'сгнивший' [СВЯ: 405], Purde- 'родник' [СВЯ: 440], Sara- '(небольшой) приток реки’ [ПФГЛ: 88], Vadai‘болото, поросшее плохо растущим лесом’ [ПФГЛ: 99] и др. Все они действительно имеют ограниченный ареал бытования в топонимии Олонецкой Карелии [Топонимический атлас Карелии]. При этом достаточно сложно говорить что-либо о времени появления этих моделей в топонимии Карелии. Нельзя исключать, что, по крайней мере, часть из них может восходить к эпохе Средневековья, вероятно, позднего.

Отметим также, что многие из представленных выше моделей фиксируются вдоль реки Важинки, которая являлась ранее важной водной магистралью, ведшей из новгородских земель через территорию проживания средних людиков в Заонежье и далее на север. На достаточно раннюю освоенность этого водно-волокового маршрута вепсами указывает и само название реки, в котором скрывается ныне утраченный вепсским языком географический термин vad'ž- (*vats $V)$ со значением 'болотный массив, заболоченная территория, довольно обширное болото’ [Муллонен 2002: 289].

Поскольку юго-восточное Приладожье, поделившееся на вепсское Присвирье и карельскую Олонецкую Карелию, было в прошлом единым этнокультурным и этноязыковым ареалом, здесь стоило бы ожидать, в том числе, и определенного сходства ойконимии. В частности, на это может указывать распространение ойконимной модели на -ичи/-ицы в наименованиях поселений, ср. вепс. терр. Каргиничи, Киковичи, Кургениџы - кар. терр. Игачениџы, Кярбиницы, Пергиницы и др. В данном контексте было бы интересно, например, выявить примарные наименования олонецких населенных пунктов рассматриваемого типа и попытаться понять, могли ли они существовать здесь в вепсское время или же их появление стало уже результатом освоения Олонецкой равнины карелами, переселившимися сюда из северозападного карельского Приладожья. Одним из критериев подобной выборки может быть общность антропонимических основ на обеих территориях и их отсутствие в других восточных прибалтийскофинских ареалах расселения. Данный вопрос, безусловно, требует специального исследования. Ниже 
нами предварительно представлен ряд названий населенных пунктов или их частей, в наименовании которых можно усматривать вероятную связь вепсских территорий и современной южной Карелии: ср. вепс. терр. Герпеничи - кар. терр. Нӧrрӓl (Герпяля), вепс. Канжела - кар. Kanzoi, вепс. Kingl кар. Кинкиева, вепс. Кинницы - кар. Кinni, вепс. Кожела - кар. Kоžаl (Кожала), вепс. Куневичи кар. Kun'oilu (Куневицы), вепс. Nirgl (Ниргиничи) - ? кар. Nirka, вепс. Нуроля - ? кар. N’ural (Нюрала), вепс. Pečal (Печеницы) - ? кар. Päč(č)il (Пятчила), вепс. Пижевичи — кар. Piži (Обжа), вепс. Юксовичи кар. Juoksiilu (Юксилицы). Несомненно, далеко не все из представленных выше названий могли существовать в вепсский период истории Олонецкой Карелии, на что указывают, например, современные бесформантные формы ряда ойконимов. В то же время отсутствие представленных антропонимических основ на других карелоязычных территориях дает основания предполагать, что они могут иметь по крайней мере общие антропонимические истоки в Присвирье и современной южной Карелии. При этом часть из представленных выше населенных пунктов с локативным прибалтийско-финским формантом -la (рус. -ичu/-ицы) теоретически могла быть основана непосредственно присвирскими вепсами, осваивавшими некогда Олонецкую равнину. Другой вопрос — время их возникновения.

\section{Карелы}

В наше время практически невозможно выявить древнекарельские топонимические типы, появление которых можно было бы увязывать с эпохой Средневековья. Считается, что начало регулярного освоения древними карелами современной территории Карелии ${ }^{15}$ восходит к XIII в. [Бубрих 1947: 37]. Однако нельзя при этом исключать возможности, что ранние промысловые поездки карел могли относиться и к более раннему периоду, хотя этому мы не можем привести никаких доказательств. Возможно, об этом свидетельствуют, например, древнескандинавские письменные источники (саги и т. д.), повествующие о пребывании древних карел на севере Норвегии.

\section{Выводы}

По данным археологии можно проследить историю Карелии на протяжении 8-9 тысяч лет. При этом определение языковой принадлежности представителей ранних археологических культур, а также сколько-нибудь точную реконструкцию языка или языков этого населения большинство ученых считают в настоящее время невозможными. Этническая принадлежность аборигенного населения становится очевидной начиная с первых веков первого тысячелетия нашей эры. Языковой пласт древних палеоевропейцев можно сегодня видеть в языке современного саамского населения, а также в топонимии Карелии и сопредельных областей, где для многих названий крупных гидрографических объектов нередко не находится убедительных этимологий из саамских и прибалтийско-финских языков. Таким образом, можно предполагать, что древние саамы ассимилировали в первой половине первого тысячелетия нашей эры живших здесь представителей ранних археологических культур, говоривших на неизвестных науке древних языках.

В железном веке и раннем Средневековье в Карелии развивалась культура лесных саамов. Языковые данные свидетельствуют, что на рубеже первого и второго тысячелетия именно древние саамы населяли большую часть территории современной Карелии и сопредельных территорий. Следы их пребывания здесь лучше всего сохранились в топонимии, а также в заимствованной в карельский, вепсский и русский языки лексике. Топонимы саамского происхождения фиксируются в большом количестве в средних и северных частях Карелии, но при этом они представлены сравнительно широко и в южной Карелии. Бо́льшая их часть - это названия крупных природных объектов. Фиксируемые здесь топонимные типы свидетельствуют, что в прошлом в Карелии был распространен саамский язык / языки, которые отличались от современных саамских языков. Подтверждением этого являются, например, языковые элементы, представленные в карельском и карелоязычной топонимии, соответствия (параллели) для которых обнаруживаются как на территории бытования различных диалектов саамских языков, так и на территории современных Архангельской, Вологодской и Ленинградской областей, где некогда также проживало древнесаамское население. Большое количество зафиксированных топонимов и лексики саамского происхождения дает возможность говорить о том, что значительная часть древнесаамского населения Карелии была ассимилирована прибалтийско-финскими новопоселенцами.

Прибалтийско-финское население в Олонецкой Карелии также является достаточно древним, при этом его основу составили представители средневековых вепсов, которые с X в. н. э. начали поэтапное

\footnotetext{
${ }^{15}$ Республика Карелия в границах до 1939 г.
} 
освоение южных частей Карелии. С XIII в. территорию Карелии начинают активно осваивать древние карелы, чья прародина находилась в северо-западном Приладожье. Со временем приладожские карелы ассимилировали и автохтонное саамское население Карелии, и большую часть переселившихся с юга вепсов.

В заключение можно еще раз отметить, что в сравнении с древними карелами, основой хозяйственной жизнедеятельности которых были промыслы (охота, рыболовство), а также торговля продуктами промысловой деятельности, древних вепсов можно считать по большей части населением, ориентированным на сельское хозяйство. Тем не менее, необходимо помнить о том, что и в хозяйственной деятельности древних карел сельское хозяйство играло все же немаловажную роль, и следы его убедительно присутствуют на территории их проживания уже начиная с конца первого тысячелетия нашей эры [Simola 2003: 110].

Сокращения

вепс. - вепсский язык

док. - документально

кар. - карельский язык

pус. - русский язык

прасаам. - прасаамский язык

саам. - саамские языки

саамК - саамские языки Кольского полуострова

саамН - саамские языки Норвегии

совр. - современный (язык, территория и т. д.)

фин. - финский язык

$$
\begin{aligned}
& \text { бол. - болото } \\
& \text { зал. - залив } \\
& \text { о. - остров } \\
& \text { оз. - озеро } \\
& \text { терр. - территория } \\
& \text { уг. - угодье }
\end{aligned}
$$

Вычет. - Вычетайбольская волость

Юшкоз. - Юшкозерская волость

\section{Литература}

Бубрих 1947 - Бубрих Д. В. Происхождение карельского народа. Петрозаводск, 1947. \{Bubrikh D. V. The origin of the Karelian people. Petrozavodsk, 1947.\}

Дуров 2011 - Дуров И. М. Словарь живого поморского языка в его бытовом и этнографическом применении. Петрозаводск, 2011. \{Durov I. M. Dictionary of the living Pomor language in its everyday and ethnographic application. Petrozavodsk, 2011.\}

Жуков 2000 - Жуков А. Ю. Формирование и развитие структуры церковного управления в Карелии (XIII—XV вв.) // Православие в Карелии. Материалы республиканской научной конференции $24-25$ октября 2000 г. Петрозаводск, 2000. С. 40-47. \{Zhukov A. Yu. Formation and development of the structure of church government in Karelia $\left(13^{\text {th }}-15^{\text {th }}\right.$ centuries $) / /$ Orthodoxy in Karelia. Petrozavodsk, 2000. P. 40-47.\}

Жуков 2004 - Жуков А. Ю. Саами в XIII-XVII вв. (публикация источников и комментарий) // Антропол. форум. Современные тенденции в антропологических исследованиях. 2004, 1. С. 298-322. \{Zhukov A. Yu. The Sami People in the $13^{\text {th }}-17^{\text {th }}$ Centuries (Publication of Sources and Comments) // Anthropological forum. Modern trends in the anthropological researches. 2004, no. 1. P. 298-322.\}

Жуков 2008 - Жуков А. Ю. Сямозерье в XIV-XVII веках // История и культура Сямозерья. Петрозаводск, 2008. C. $41-106$. \{Zhukov A. Yu. Syamozerie in the $14^{\text {th }}-17^{\text {th }}$ centuries // History and culture of Syamozero. Petrozavodsk, 2008. P. 41-106.\}

Захарова, Макарова, Муллонен 2016 - Захарова Е. В., Макарова А. А., Муллонен И. И. В поисках топонимических границ в Белозерье // Вопросы ономастики. 2016. Т. 13. № 1. С. 7-29. \{Zakharova E. V., Makarova A. A., Mullonen I. I. In Search of Toponymic Borders in Belozerye // Problems of onomastics. 2016. Vol. 13. № 1. P. 7-29.\}

История Карелии - История Карелии с древнейших времен до наших дней. Петрозаводск, 2001. \{The History of Karelia from Ancient Times to the Present Day. Petrozavodsk, 2001.\}

Конкка 2013 - Конкка А. Карсикко: деревья-знаки в обрядах и верованиях прибалтийско-финских народов. Петрозаводск, 2013. \{Konkka A. Karsikko: trees-signs in the rites and beliefs of the Baltic-Finnish peoples. Petrozavodsk, 2013.\}

Косменко 1996а - Косменко М. Г. Основные проблемы и задачи теории и методики изучения древностей Карелии // Археология Карелии. Петрозаводск, 1996. С. 8-35. \{Kosmenko M. G. The main problems and tasks of the theory and methods of studying the antiquities of Karelia // Archeology of Karelia. Petrozavodsk, 1996. P. 8-35.\}

Косменко 19966 - Косменко М. Г. Поселения охотничье-рыболовецких культур // Археология Карелии. Петрозаводск, 1996. С. 272-285. \{Kosmenko M. G. Settlements of hunter-fisher societies // Archeology of Karelia. Petrozavodsk, 1996. P. $272-285$. 
Косменко 2008 - Косменко М. Г. Археологические данные и этнокультурные процессы в Сямозерье // История и культура Сямозерья. Петрозаводск, 2008. С. 13-24. \{Kosmenko M. G. Archaeological data and ethnocultural processes in Syamozerie // History and culture of Syamozerye. Petrozavodsk, 2008. C. 13-24.

Косменко, Кочкуркина 1996 - Косменко М. Г., Кочкуркина С. И. Вопросы истории населения древней Карелии // Археология Карелии. Петрозаводск, 1996. С. 362-387. \{Kosenko M. G., Kochkurkina S. I. Questions of the history of the population of ancient Karelia // Archeology of Karelia. Petrozavodsk, 1996. P. 362-387.\}

Кочкуркина 1996 - Кочкуркина С. И. Весь // Археология Карелии. Петрозаводск, 1996. С. 286 - 310. \{Kochkurkina S. I. Ves’// Archeology of Karelia. Petrozavodsk, 1996. P. 286-310.\}

Кочкуркина 2006 - Кочкуркина С. И. Весь // Современная наука о вепсах: достижения и перспективы (памяти Н. И. Богданова). Петрозаводск, 2006. С. 178-211. \{Kochkurkina S. I. Ves’// Modern Science of Vepsians: Achievements and Prospects (in memory of N. I. Bogdanov). Petrozavodsk, 2006. P. 178-211.\}

Кочкуркина 2019 - Кочкуркина С. И. Вепсы в эпоху Средневековья по данным археологии // Народы Карелии: историко-этнографические очерки. Петрозаводск, 2019. С. 287-295. \{Kochkurkina S. I. Vepsians in the Middle Ages (according to archeology) // Peoples of Karelia: historical and ethnographic essays. Petrozavodsk, 2019. P. 287-295.\}

Кравченко 2007 - Кравченко A. B. Конспект флоры Карелии. Петрозаводск, 2007. С. 403. \{Kravchenko A. V. Abstract of the flora of Karelia. Petrozavodsk, 2007.\}

Криничная, Пулькин 1971 - Криничная Н., Пулькин В. Фонограммархив ИЯЛИ КарНЦ РАН 135, № 27; Фонотека, 1628/3. \{Krinichnaya N., Pulkin V. Phonogram archive of ILLH KRC RAS 135, № 27; Phonoteca, 1628/3.\}

Кузьмин 2016 - Кузьмин Д. В. История освоения карельского Поморья (в свете языковых данных) // Linguistica Uralica. 2016, 3. C. 179-194. \{Kuzmin D. V. History of the development of the Karelian Pomorie (in the light of language data) // Linguistica Uralica. 2016, 3. P. 179-194.\}

Кузьмин 2020 - Кузьмин Д. В. Словарь карельской народной географической терминологии. Петрозаводск, 2020. \{Kuzmin D. V. Dictionary of Karelian folk geographic terminology. Petrozavodsk, 2020.\}

Куликовский 1898 - Куликовский Г. И. Словарь областного олонецкого наречия в его бытовом и этнографическом применении. Санкт-Петербург, 1898. \{Kulikovsky G. I. The dictionary of regional Olonets dialect in its everyday and ethnographic use. Saint Petersburg, 1898.\}

Мамонтова, Муллонен 2008 - Мамонтова Н. Н., Муллонен И. И. Топонимия как отражение этнического прошлого Сямозерья // История и культура Сямозерья. Петрозаводск, 2008 С. 25-38. \{Mamontova N. N., Mullonen I. I. Toponymy as a reflection of the ethnic past of the territory of Lake Syamozero // History and culture of Syamozerye. Petrozavodsk, 2008.\}

Муллонен 1994 - Муллонен И. И. Очерки вепсской топонимии. Санкт-Петербург, 1994. \{Mullonen I. I. Essays on Vepsian Toponymy. Saint Petersburg, 1994.\}

Муллонен 2002 - Муллонен И. И. Топонимия Присвирья. Проблемы этноязыкового контактирования. Петрозаводск, 2002. \{Mullonen I. I. Toponymy of the Svir region: problems of ethno-linguistic contact. Petrozavodsk, 2002.\}

Муллонен 2007 - Муллонен И. И. Загадка Выга // Комплексные гуманитарные исследования в бассейне Белого моря. Петрозаводск, 2007. С. 200-203. \{Mullonen I. I. Riddle of Vyg // Comprehensive Humanitarian Research in the White Sea Basin. Petrozavodsk, 2007. P. 200-203.\}

Муллонен 2011 - Муллонен И. И. Людики на топонимической карте Карелии // Историко-культурный ландшафт Северо-Запада. Четвертые Шегреновские чтения. СПб, 2011. С. 229-239. \{Mullonen I. I. Lydic Karelians on the toponymic map of Karelia // Fourth Sjögren's Readings. Saint Petersburg, 2011. P. 229—239.\}

Муллонен 2012a - Муллонен И. И. Что означает «Карелия» и «Ладога» // Тысячелетний Сортавала: исторические ландшафтные театры. Сортавала, 2012. С. 10-11. \{Mullonen I. I. What do "Karelia" and "Ladoga" mean // Millennial Sortavala: historical landscape theaters. Sortavala, 2012. P. 10-11.\}

Муллонен 20126 - Муллонен И. И. Природные и культурные факторы формирования вепсской этнической территории // Труды Карельского научного центра РАН. 2012, 4. С. 13-24. \{Mullonen I. I. Natural and cultural factors shaping Vepsian ethnic territory // Transactions of the Karelian Research Centre of the Russian Academy of Sciences. 2012, 4. P. 13-24.\}

Муллонен 2018 - Муллонен И. И. Фонетические варианты древней топоосновы *Ylä- 'верхний' и их генезис в гидронимии Карелии // Вопросы ономастики. 2018. Т. 15. № 2. С. 7-27. \{Mullonen I. I. Phonetic Variants of the Ancient Toponymic Stem *Ylä- 'Upper' and Their Genesis in the Hydronymy of Karelia // Problems of onomastics. 2018. Vol. 15. № 2. P. 7-27.\}

Муллонен 2019 - Муллонен И. И. Территория расселения и этнонимы вепсов // Народы Карелии: историкоэтнографические очерки. Петрозаводск, 2019. С. 304-313. \{Mullonen I. I. The territory of settlement and ethnonyms of the Vepsians // Peoples of Karelia: historical and ethnographic essays. Petrozavodsk, 2019, Р. 304-313.\}

Напольских 2006 - Напольских В. В. Булгарская эпоха в истории финно-угорских народов Поволжья и Предуралья // История татар с древнейших времен в семи томах. Том 2. Волжская Булгария и Великая Степь. Казань, 2006. C. 100-115. \{Napolskikh V. V. The Bulgar era in the history of the Finno-Ugric peoples of the Volga region and the 
Urals // History of the Tatars from ancient times in seven volumes. Volume 2. Volga Bulgaria and the Great Steppe. Kazan, 2006. P. $100-115$.

НПЛ 1950 - Новгородская первая летопись. М.-Л., 1950. \{The Novgorod First Chronicle. Moscow — Leningrad, 1950$.

HТА - Научный топонимический архив ИЯЛИ КарНЦ РАН. \{The Names Archive of Karelia. ILLH KRC RAS.\}

Окороков 2005 - Окороков $A$. В. Словарь терминов, употребляемых беломорскими рыбопромышленниками и судостроителями // Сост. Э. Л. Базарова, Н. В. Бинадзе, А. В. Окороков, Е. Н. Селезнева, П. Ю. Черносвитов. Культура русских поморов. Опыт системного исследования. М., 2005. \{Okorokov $A$. $V$. Glossary of terms used by the White Sea fishers and shipbuilders // Culture of Russian Pomors. Systems research experience. Moscow, 2005.\}

Пашков 2003 - Пашков А. М. «Житие Лазаря Муромского» в истории культуры Карелии XVIII-XX вв. // Кижский вестник. 2003, 8. С. 3-13. \{Pashkov A. M. Hagiography of Lazar Muromskiy in the history of culture of Karelia in the $18^{\text {th }}-20^{\text {th }}$ centuries // Kizhi Bulletin. 2003, 8. P. 3-13.\}

Пименов 1965 - Пименов В. В. Вепсы: очерк этнической истории и генезиса культуры. М.-Л., 1965. \{Pimenov V. V. Vepsians. Essay on ethnic history and genesis of culture. Moscow — Leningrad, 1965.\}

ПКВП - Писцовая книга Вотской пятины 7008 года. Временник Моск. об-ва истории и древностей российских 11. M., 1851. \{Census Book of Votskaya pyatina of the Year 7008 (1499/1500). Annals of the Imperial Moscow society of history and antiquities of Russia. Moscow, 1851.\}

ПКОП - Писцовые книги Обонежской пятины 1496 и 1563 гг. Выпуск 1. Материалы по истории Карельской АССР. Л., 1930. \{Census books of the Obonezhskaya pyatina in 1496 and 1563. Iss. 1. Leningrad, 1930.\}

Подвысоцкий 1885 - Подвысоцкий А. И. Словарь областного архангельского наречия в его бытовом и этнографическом применении. СПб., 1885. \{Podvysotskiy A. O. Dictionary of the regional Arkhangelsk dialect in its everyday and ethnographic usage. Saint Petersburg, 1885.\}

ПРП 1953 - Памятники русского права. Выпуск 2: Памятники права Великого Новгорода (XII-XV вв.). M., 1953. \{Monuments of Russian law. Issue 2: Monuments of the law of Veliky Novgorod (XII-XV centuries). Moscow, 1953.\}

ПФГЛ - Прибалтийско-финская географическая лексика Карелии / Сост. Н. Н. Мамонтова, И. И. Муллонен. Петрозаводск, 1991. \{Baltic-Finnish geographical vocabulary of Karelia by Mamontova N. N., Mullonen I. I. Petrozavodsk, 1991.\}

РС 1782 - Ревизские сказки государственных крестьян Олонецкого уезда Олонецкого погоста, Верховской Мегрегской трети, Чилмозерской, Коткозерской волостей, г. Олонца НАРК, ф. 4, оп. 18, д. 4/21, л. 355. \{Revision lists of the state peasants of the Olonets uyezd of the Olonets churchyard. NARK, f. 4, op. 18, d. 4/21, 1. 355.\}

РС 1834 - Ревизские сказки государственных крестьян Олонецкого уезда Туломозерской вотчины Ведлозерского, Крошнозерского, Туломозерского старощений. НАРК, ф. 4, оп. 18, д. 48/455, л. 104 об. \{Revision lists of the state peasants of the Olonets uyezd. NARK, f. 4, op. 18, d. 48/445, 1. 104.\}

СВЯ - Словарь вепсского языка / Сост. М. И. Зайцева, М. И. Муллонен. Л., 1972. \{Dictionary of the Vepsian language by M. I. Zaitseva, M. I. Mullonen. Leningrad, 1972.\}

СКЯ - Словарь карельского языка / Сост. Г. Н. Макаров. Петрозаводск, 1990. \{Dictionary of the Karelian language by G. N. Makarov. Petrozavodsk, 1990.\}

Топонимический атлас Карелии - Захарова Е. В., Кузьмин Д. В., Муллонен И. И. Топонимический атлас Карелии (рукопись). \{Zakharova E. V., Kuzmin D. V., Mullonen I. I. Toponymic Atlas of Karelia (manuscript).

Фасмер 1986 - Фасмер М. Этимологический словарь русского языка. M, 1986. \{Fasmer M. Etymological dictionary of the Russian language. Moscow, 1986.\}

Aikio 2009 - Aikio A. The Saami Loanwords in Finnish and Karelian. Oulu, 2009.

Bergsland 1995 — Bergsland K. Bidragtil sydsamenes historie. Skriftserie: Senter for samiske studier, № 1, Senter for samiske studier. Tromsø, 1995.

Carpelan 2003 - Carpelan C. Inarilaisten arkeologiset vaiheet // Inari - Aanaar. Inarin historia jääkaudesta nykypäivään. Oulu, 2003. S. 28-95.

Elo, Seppälä 2011 - Elo T., Seppälä S. Vesistöjä ja vaaramaisemia. Kemijärven kulttuuriympäristöohjelma. Lapin elinkeino-, liikenne- ja ympäristökeskus. Suomen ympäristö 22. Ympäristöministeriö. Helsinki, 2011.

Engelberg 1912 - Engelberg $R$. Kansantietoja Pohjois- ja Itä-Suomesta ja Venäjän-Karjalasta. Koonnut ja julkaissut Rafael Engelberg. Helsinki, 1912.

Grünthal 1997 - Grünthal R. Livvistä liiviin. Itämerensuomalaiset etnonyymit. Helsinki, 1997.

Halinen 2011 - Halinen P. Arkeologia ja saamentutkimus // Saamentutkimus tänään. Toim. Irja Seurujärvi-Kari, Petri Halinen ja Risto Pulkkinen. Tietolipas 234. Helsinki, 2011. S. 130-176.

Itkonen 1986 - Itkonen E. Inarilappisches Wörterbuch I-III (1986-89). LSFU 20. Helsinki, 1986.

Itkonen 2011 — Itkonen T. I. Koltan- ja Kuolanlapin sanakirja I-II. LSFU 15. Helsinki, 2011.

KKS - Karjalan kielen sanakirja. Lexica Societatis Fenno-Ugricae XVI. Helsinki. https://kaino.kotus.fi/cgibin/kks/karjala.cgi. 
Korhonen 1938 - Korhonen A. Suomen itärajan syntyhistoriaa. Helsinki, 1938.

Korhonen 1981 - Korhonen M. Johdatus lapin kielen historiaan. Helsinki, 1981.

Krohn 1894 - Krohn J. Suomen suvun pakanallinen jumalanpalvelus. Suomalaisen Kirjallisuuden Seuran toimituksia 83. Suomalaisen Kirjallisuuden Seura. Helsinki, 1894.

Kuzmin 2013 - Kuzmin D. Saamelaisen asutuksen vaiheita Karjalassa // Suomalais-Ugrilaisen Seuran Aikakauskirja. 2013, 94. S. 69-124.

Kuzmin 2015 - Kuzmin D. Vienan Karjalan asutus perimätiedon ja sukunimiaineiston valossa // Suomalais-Ugrilaisen Seuran Aikakauskirja. 2015, 95. S. 145-199.

Laasonen 2005 — Laasonen P. Novgorodin imu. Miksi ortodoksit muuttivat Käkisalmen läänistä Venäjälle 1600-luvulla. Helsinki, 2005.

Lehtiranta 1989 - Lehtiranta J. Yhteissaamelainen sanasto. SUST 200. Helsinki, 1989.

Leppäaho 1935 - Leppäaho J. Ns. «lapinpattahat» (Sk. «lappstolpar») // Kotiseutu. 1935, 1. S. 38 - 49.

LMS — Lyydiläismurteiden sanakirja. Toim. Juho Kujola. Suomalais-ugrilainen seura. Helsinki, 1944.

Mattus 2010 - Mattus Ilmari. Itä-Inarin paikannimistö. Metsähallituksen luonnonsuojelujulkaisuja. Sarja A. Helsinki, 2010.

NA — Nimistöarkisto. Kotimaisten kielten tutkimuskeskus. Helsinki.

Nielsen 1979 — Nielsen K. Lapp Dictionary. Vol. 1-5. Oslo, 1979.

Pöllä 2001 - Pöllä M. Vienankarjalainen perhelaitos 1600-1900. SKS. Helsinki, 2001.

Saarikivi 2006 - Saarikivi J. Substrata Uralica: Studies on Finno-Ugrian Substrate in Northern Russian Dialects. Tartu, 2006.

Saarikivi 2011 - Saarikivi J. Saamelaiskielet - nykypäivää ja historiaa // Saamentutkimus tänään. Toim. Irja Seurujärvi-Kari, Petri Halinen ja Risto Pulkkinen. Tietolipas 234. Helsinki, 2011. S. 77-119.

Saksa 1998 - Saksa A. Vepsäläiset - Pohjolan muinainen kansa // Vepsä: Vepsänmaa. Oulu, 1998. S. 120 - 125.

Simola 2003 - Simola H. Karjalan luonto ja ihminen // Karjalan synty. Viipurin läänin historia I. Lappeenranta, 2003. S. $81-115$.

Sjögren 1861 - Sjögren J. A. Aufzeichnungen über die Gemeinden in Kemi-Lappmarken // J. A. Sjögren. Gesammelte Schriften, Band I. Sankt-Peterburg, 1861. S. 85-232.

SSS — Sami-suoma satnegirji. Pekka Sammallahti. Jorgaleaddji Oy. Ohcejohka, 1989.

Suvanto 1972 - Suvanto S. Satakunnan ja Hämeen keskiaikainen rajalaitos. Tampere, 1972.

Valonen 1980 - Valonen N. Varhaisia lappalais-suomalaisia kosketuksia // Ethnologia Fennica 10. Helsinki, 1980. S. $21-98$

Vilkuna 1971 — Vilkuna K. Mikä oli lapinkylä ja sen funktio // Kalevalaseuran vuosikirja. 1971, 51. S. 201 -236. 